\title{
Ács Pál, Reformations in Hungary in the Age of the Ottoman Conquest, Göttingen, Vanden- hoeck und Ruprecht, 2019 (Refo500 Academic Studies, 52). 333 p.
}

Milyen helyzetben vannak a magyar történeti szakirodalom világnyelvű reprezentációját célzó programok? Elégségesek-e a szakmák képviselöi, a szakmai intézmények, illetve a magyar tudománypolitika ezzel a céllal összefüggő erőfeszítései? A kérdés megválaszolása soha sem volt egyszerü, és ma is sokféle szempont mérlegelendő ezzel kapcsolatban. Sokan azt mondják, hogy a hasonló témakörökben jobb, ha nincsen határozott és tevékeny kormányzati politika. Azért jobb, mert a magyarok, ha valaki ki akar tünni közülük, inkább visszahúzzák, semmint örülnének a közülük valók sikerének. „Bezzeg a románok” - emlegetik az önmagukon elkeseredettek. Románia, a legszegényebb állapotában is, még kommunista színeiben is követte azt a nemzetpolitikai célt, amelyet akkor fogalmaztak meg román értelmiségiek, amikor Románia még nem volt, sokáig nem volt, vagyis még a 18. században. A Román Királyság létrejötte után pedig a nemzetközi kiállásban mindig egységesnek mutatkoztak. Ma is, sok szempontból tervezetten folyik a román történelmi kérdések angol nyelvủ taglalása. Merthogy manapság angolul kell taglalni. Hiszen azok sem olvasnak más nyelven, akiknek a történelmi forrásaik nagyobb része németül, vagy éppen olaszul, netán magyarul, és gyakran latinul van. De ha angol, akkor publikáljunk angolul. (Lassan már a Mediterraneumban is elfogadják.)

Igen ám, de mit adjunk ki angolul? Ács Pál kötete tanúsítja, hogy amellett, hogy van mit, lehet ezt úgy is tenni, hogy ne csak a nemzetközi publikum tanuljon belőle. A magyar is. Nem egyszerüen néhány aktualizáló lábjegyzetet ismerhetünk meg a tanulmányok korábbi magyar kiadásához képest, hanem szemléletet is tanulhatunk. Saját ismereteinknek is szükségük van arra, hogy úgy is átgondoljuk mondandónkat, hogy elképzeljük a külföldi olvasót, annak feltételezett ismereteit, és szemléletét. A mai politikai korrektséget istenítők nyelvezetével: „érzékenyítjük magunkat” arra, hogy elfogadjuk, mások, másként látják ugyanazt a dolgot. Olyan megállapításokat is teszünk a világnyelven megjelent szövegben, amely szempont, magyarul, magyar szakmai közönségnek írva, nem is jut eszünkbe. Az alapkérdés persze marad: milyen nem magyar közönséget képzeljünk el? Angolt, mert angolul írunk? - akkor minden tanulmányunk kétszer ilyen hosszú lenne, hiszen a legelemibb dolgot is el kellene magyaráznunk, a tudományos értekező próza gyakorlatilag kizárható lenne. Tapasztalatom szerint a legtöbb angol nyelven megjelent publikáció is alapvetően németeknek szól, és a manapság a németet, a buta aktuálpolitikai szempontok miatt elfelejtő közép-európaiaknak. Ács Pál tanulmánykötete tematikusan ráadásul a protestáns reformáció körül forog, vagyis nem csupán a természetes érdekszféra köti ezeket az írásokat a németekhez.

Nem kezdhette a szerző a kötetét egy szellemes előszóval, amelyben az „elváltozott”, az ,átszitált" „idő ódájá”-ra utalhatna. Pedig a kötet a három idő, és a három, a címében az „idő”-vel játszó könyvének újragondolása is (egy idegen olvasónak egy ilyen utalás érthetetlen lenne). A kérdésfeltevések maradtak az egyes tanulmányokban, de a gondolatmenet lendülete, kis részletekben szelleme is változott. Az előszó így, egy pátoszmentes, korrekt bevezetés. A pátosz, a búslakodás - koraújkori történelmünk különösen sok okot ad erre - persze megbújik a tanulmányok hátterében. „Mutato nomine de te fabula narratur”. Vagyis benne van a könyvben a három részre szakított, középkori hatalmi helyzetét veszített ország, a többször feldúlt, és megsemmisített kulturális és egyházi intézményrendszer, csak ez nem a kesergő prím. Tudni lehet erről az egyes történetek alapján, az egyes történetek mögött. Amit viszont 'expressis verbis' megír a szerző, az éppen egy európai történet. Ha nem is mondja (mert felesleges lenne), bizony, ,,mindig a nyugati keresztény Európa része voltunk". Akit érdekel a történet, ezt is érti belöle, akit meg nem érdekel, nem is olvassa. De mi is ez a „kicserélt" (átváltozott) név ('nomen mutatum')?

Reformations. Ez a többes szám hallatlanul fontos egy olyan kiadványban, amelyik a protestáns reformáció 500 éves történetének ünnepsorozata részeként jelent meg. A sok kiadó közül, amelyik 
ilyen emlékező sorozatokat adott ki, a Vandenhoeck und Ruprecht csak egy, és az ő Ref500 sorozatának Ács Pál kötete az 52. darabja. Mintha a németek azt is megmutatták volna, hogy egy emlékév nem csupán egy év, és legalább tíz évvel elötte tudni kell, hogy lesz, és nem a tárgyév augusztusában kell dönteni arról, hogy miként emlékezzünk. De ez csak keserü megjegyzés. A reformok sokfélék voltak mindig, a 16. században pedig minden, amit Európában tudottnak és elrendezettnek hittek, alapvető reformra szorult. Az egyház reformja csak következménye a világról és a hitbéli dolgokról való gondolkodás megváltozásának.

A könyv első fejezete (Erasmian Challenges) tehát amellett, hogy bemutatja a németalföldi humanista magyar királyságbeli kapcsolatait, második írásával bizonyítja, hogy volt eszmei, tartalmi recepció is a kapcsolatok mögött. Az is kiderül, hogy a keresztény filozófus Erasmus hatása jelentősebb (és elválaszthatatlan) az egyházkritikus, pontosabban a butaság-kritikus értelmiségiénél. Hiszen Erasmus neve nem a Balgaság dicsérete miatt maradt fenn - Sebastian Brant népszerübb volt nála (Bolondok hajója) -, hanem a Melanchthonnak és Sturmnak mintául szolgáló filozófiája miatt. Fontosnak gondolom, hogy a magyar példák is megerősítik ezt a képet, hiszen napjaink az „Európa-mibenléte-irodalom” számos, jól sztárolt darabja éppen Erasmust és Luthert próbálja a laikus, a másokat elfogadó, a toleráns társadalom szükségességét megfogalmazóknak eladni.

Ács Pál könyve magyar példákkal ismerteti meg a nemzetközi szakmai közösséget azzal kapcsolatban is, hogy a vernakuláris irodalmak (esetünkben, a magyar nyelvű irodalom) kialakulása és megerősödése sem egy leegyszerüsített, előzmények nélküli módon történt. Vagyis úgy, hogy jött a reformáció, és vele megszületett a magyar (és sok más) nyelvü irodalom. Természetesen a magyar példa is azt mutatja, hogy a protestáns tanok rendszerszerü terjesztése mentén lesz mennyiségileg jelentős, és irodalmi múfajaiban a nyugat-európai mintákat naprakészen befogadó több nemzeti irodalom (második fejezet: Protestant Reformations in Cultural Context). A középkori egyház keretin belül kialakult igényre adott egyházi értelmiségi válaszok készítették elö mindenütt ezt a változást, és az új egyházak alapítása „csupán” az állandó (keresztény) vallás értékeinek megmentését célozta. A humanista filológia eredményei mentén kibővített tudással elrendezett, és gazdagított értékekről van szó. Ács Pál természetesen felmutatja azokat a müvelődéstörténetileg fontos alakokat, és müveiket, amelyeket a korban is ismertek a kortársak Európában, és ma is ismerniük kell azoknak, akik a 16. századi Európa művelődési térképét rajzolják. Minőségi 'hungarológia': olyan alakokhoz köt nemzeti értékeket, akik nem ismeretlenek azoknak sem, akiknek az új üzenetet szánták. Így tudják kontextualizálni a saját kulturális örökségükben is, és az új üzenet beszédmódja is olyan, hogy értik, akiket megcélzott. Nem belterjesen magyar. És így, tematikusan olyan téma is belefér a kötetbe, amelyet kevesen értenek nyugatabbra, vagy éppen délebbre tölünk, hiszen az unitárius tanok mély ismereten alapuló bemutatása nagy megfontoltságot kíván, ha mondandónkat az érthetőség szintjén akarjuk tartani.

A harmadik fejezet tulajdonképpen egy európai szakirodalmi évtizednek is összegzése, illetve annak kései gazdagítása (The Changing Image of Ottoman Turks). A „török-kérdés”, a „törökök ismerete”, az „ellenség ismerete” ugyanis hosszú ideig témája volt kutatási programoknak, konferenciáknak, kiállításoknak, és egyetemi kurzusoknak. Miként jutott el az európai értelmiség a „kutyafejü" mongoloktól a tudományos néprajzi, népismereti, és művelődéstörténeti megközelítésekig, leírásokig, már ami az oszmán törököket illeti. És itt is a magyar hozadék: a törökkel napi szinten való érintkezés előnyei a megismerésben. Fogságok, barátságok, vallásismeret, tudós kapcsolatok. Mindezt az elengedhetetlen politikatörténeti kontextusban. Nagyon fontos, hogy Ács Pál nem sztereotípiákat ismételget, hanem konkrét történeteket ad elö, mutat be, és igazán mélyen értékeli azt, hogy a magyar szereplők a jelzet megismerési folyamatban hol tartanak a 16. század elejétől a 17. század elejéig. Külön alfejezet Zalánkeméni Kakas István perzsiai diplomáciai küldetésének szövegemléke, a titkára által könyvvé formált Iter Persicum. Ennek ugyan a perzsiai része nagyon sovány, hiszen a követ Perzsia határán meghalt, azonban a követség elhelyezése a korban, 
az útleírás értékelése és nyelvi verzióinak bemutatása a lényeg. Újdonság a tervezett angol fordítás kézirata, és ennek a keletkezéstörténete. Mondjuk, én nem mondanám Kakas Istvánt kozmopolitának, hiszen ez a szó nem illik a koraújkort leíró kifejezések sorába.

A reformok idejében a soron következő a katolikus reform, ez a negyedik fejezete a könyvnek (The Catholic Reforming Movements int he Early $17^{\text {th }}$ Century). A török téma átkötése Esterházy Pál és Kunstkabinetje, avagy az Egy csudálatos ének elemzése. Magam, a magyar gondolkodástörténetben, a politikai gondolkodás történetében, sőt, a magyar mentalitástörténetben alapvető jelenségnek tartom azt, amit Ács Pál leírt Pázmány Péter beszédei kapcsán. Nem egyszerüen a katolikus és a protestáns történetfilozófiai, adott kérdésekben teológiai felfogás különbözősége az érdekes, hanem a közös hatása a két felekezeti beszédmódnak, illetve a beszédek tartalmi szemléleti elemeinek. És ezek, köszönhetően a minden stíluskorszakban megszületett, közvetítő magyar irodalmi szövegeknek, máig élnek.

MONOK IsTváN

\begin{abstract}
A Gyulafehérvári Római Katolikus Papnevelö Intézet „Seminarium Incarnatae Sapientiae” Könyvtárának régi állománya I., összeáll. Szügyi-Szücs Judit, Veres Anna Mária, Magyar Tudományos Akadémia Könyvtár és Információs Központ, Budapest, 2019 (A Kárpát-medence magyar könyvtárainak régi könyvei, 12). 142 p.
\end{abstract}

A nyomtatott nemzeti kulturális örökség feltárását, nyilvántartását és szélesebb körű felhasználásra való előkészítését tűzte ki célul a program, amely a Kárpát-medencében található magyar könyvtárak régi könyvállományát veszi számba. A másfél évtizede megkezdett feltárási munkát Monok István, a Magyar Tudományos Akadémia Könyvtár és Információs Központ főigazgatója koordinálja, összefogó munkájának eredményeképpen eddig tizenkét kötet látott napvilágot. A katalógusok nagyobbik része Erdélyben található magyar könyvtárak régi könyveinek jegyzékét teszi közkinccsé (A Nagyváradi Római Katolikus Egyházmegyei Könyvtár régi állományának két kötete, 2005, 2008; Az egykori nagyenyedi minorita rendház könyvtárának régi állománya, 2009; A kaplonyi ferences rendház könyvtárának régi állománya, 2009; A Szatmári Római Katolikus Egyházmegye Müemlékkönyvtárának régi könyvei, 2010; A kolozsvári Protestáns Teológiai Intézet Könyvtárának régi állománya, 2015; A Gyulafehérvári Római Katolikus Papnevelö Intézet „, Seminarium Incarnatae Sapientiae” Könyvtárának régi állománya, 2019), egy kötet a Felvidékről (A füleki ferences rendház könyvtárának régi állománya, 2012), és szintén egy a Vajdaság területén elhelyezkedő magyar könyvtárból származik ( zombori kármelita rendház könyvtárának régi állománya, 2015). A mai Magyarország területét a Szegedi Tudományegyetem Egyetemi Könyvtár régi könyveinek három kötetben megjelent katalógusa képviseli (A Szegedi Tudományegyetem Egyetemi Könyvtár 1701 elötti nyomtatványai, 2010; A Szegedi Tudományegyetem Egyetemi Könyvtár 17011800 közötti régi nyomtatványai, 2016; A Szegedi Tudományegyetem Egyetemi Könyvtár 18011850 közötti régi nyomtatványai, 2018). A jelen recenzió tárgyát képező tizenkettedik kötet egyik összeállítója, Szügyi-Szücs Judit szintén szegedi kötődésű, a Szegedi Tudományegyetem Klebelsberg Kuno Könyvtár munkatársa, míg szerzőtársa, Veres Anna Mária, a Gyulafehérvári Római Katolikus Hittudományi Föiskola Könyvtárának könyvtárosa.

A Gyulafehérvári Római Katolikus Papnevelő Intézet Könyvtára régi állományának katalógusa 246 régi könyvet vesz számba, nem megfeledkezve a nem fellelt, de a leltárak szerint az állomány részét képező kötetekről sem. A munka két nagyobb egységre osztható. Az első az 1601 előtt megjelent antikvákat gyüjti csokorba, míg a második a Régi Magyar Könyvtár gyüjtőkörébe tartozó darabokat térképezi fel. A kötetet háromnyelvü - magyar, román és német - előszó vezeti be, amely 